\title{
Airport ownership and management in European Union countries, BOT applications in Turkey, and suggestions for Turkey
}

\author{
Yıldırım Saldıraner ${ }^{1,2}$ \\ ${ }^{1}$ Assoc. Prof. Dr. / Atılım University, School of Civil Aviation, Chairperson of Civil Aviation Management Department, Incek, 06836, \\ Ankara, Turkey \\ ${ }^{2}$ Consultant to the Turkish Civil Aviation Council of the Union of Chambers and Commodity Exchanges of Turkey
}

\section{Email address:}

ysaldiraner@atilim.edu.tr (Yıldırım Saldıraner)

\section{To cite this article:}

Yıldırım Saldıraner. Airport Ownership and Management in European Union Countries, BOT Applications in Turkey, and Suggestions for Turkey, International Journal of Economics, Finance and Management Sciences. Vol. 1, No. 2, 2013, pp. 61-67.

doi: $10.11648 /$ j.ijefm.20130102.11

\begin{abstract}
The purpose of this article is to examine the airport ownership and management applications of the European Union countries and Turkey, and to evaluate the appropriateness of the Build-Operate-Transfer (BOT) Model, which is widespread in Turkey. For this purpose, the airports at the capital cities of the European Union countries are examined in the context of applications and a general assessment is made for Turkey and suggestions are presented.
\end{abstract}

Keywords: Airport Ownership And Management, Build-Operate-Transfer Model (BOT)

\section{Introduction}

After the first successful airplane flight of the Wright Brothers in 1903, the air transport and airport operations have served as public services and have continued to grow and develop in a rapid manner as such for many years. Airports, with their complex structure where hundreds of different operations are carried out at the same time and with their known high cost of investment and operations are still under the control of public companies or institutions.

Although airports were only recognized as public services before the 1960 's, with the increase of air traffic, number of passengers and the development of commercial activities, gradually after the 1980 's, it was understood that airports could be successful and profitable business opportunities. European countries with high-density air traffic operations have improved dramatically in recent years and made remarkable profits, especially in the years 1983 to 1989 [1]. Privatization studies of airport ownership and management in Europe and in the world, partially or totally, have been initiated and still are ongoing.

Prior to going into detail about the ownership and management of airports, it is an important necessity to identify airport operations, especially the separation of air naviga- tion services. Airport and air navigation services, which although are two very different concepts complement each other and thus, need to be understood clearly. Moreover, these two services are still operated by the same governmental organizations (civil aviation authorities) in many countries. According to the International Civil Aviation Organization (ICAO), “... the operation and provision of airports and air navigation services, with roles and powers had to be clearly defined for each function" [2]. Consequently, airports must be comprehended as the places for ground handling services to the aircraft, passenger, and freight; and the air navigation services as the combination of activities given to landing, departing and flying (en-route) aircraft (in same degree, landing and departing services are also the part of airport operations). According to the ICAO's policies on charges for air navigation services, these services are being considered as non-profit (cost based) businesses [2].

In Turkey, both the state airports and air navigation services are provided by General Directorate of State Airports Authority (DHMI). However, in many European countries these services are provided by different institutions. This approach is becoming more common each year.

In accordance with the airport ownership and management assessment, airport facilities and services [3] can be 
summarized into three main sections:

Services and facilities for aircraft operations,

Services and facilities for passengers and freight,

Other services and facilities for airport support operations.

The aircraft operations are mainly related to the runways, taxiways, aprons, air navigation equipment (equipment related to landing and departing; such as ILS, MLS etc), visual aids (markings, lights, indicators, beacons, signs and markers), rescue and fire fighting, fuelling and other supporting facilities and services (such as monitoring systems, ground power supplies, electrical systems, de-icing/antiicing facilities, maintenance).

Passengers and freight services and facilities are mainly related to the terminal facilities, such as passenger services, ramp services (handling services both for passengers and for freight), and others (aircraft bridges, car parkings, catering, etc.). In Turkey and in many other countries, airport passenger terminals and related facilities are transferred to private companies under Build-Operate-Transfer (BOT) model for operation and management. Energy and air conditioning (heating/cooling) units, water supply systems, waste collecting, disposal, and recycling facilities, car parkings and CIP/VIP lounges are mostly included in the BOT projects by the airport owners.

Other services and facilities within the scope of other airport activities should be considered as; the public services (security, customs, health), office buildings and warehouses, aircraft maintenance and repair centers, transportation infrastructures (roads, railways metro connections and stations), etc.

\section{Ownership and Management Ap- proaches}

The first approach of private company ownership and management started in UK in 1986 and the British Government completely privatized British Civil Aviation Authority (BAA) by selling it to the public, including Heathrow and Gatwick, in 1987 and BAA was purchased by the Spanish Ferrovial Group, in 2006 [4]. Following the examples of successful and profitable applications, the number of privatized airports has reached to over hundred all around the world up to 2007. During these years, important financial institutions (such as Australia-based Macquarie Group) has entered the market and major airports such as Belfast, Brussels, Budapest, Copenhagen, Dusseldorf, Frankfurt, Hamburg and Rome were privatized in Europe [5]. Some of the major airports in Australia, New Zealand, Argentina, Mexico and Japan and in some African countries have been transferred to the private companies with individual applications. Canada and USA has continued to maintain public ownership of airports (In USA, joint management of airports by private companies without ownership is supported [6]). With the transfer of the management of Antalya Airport's new terminal building and related facilities to a private company by BOT Model by DHMI in 1996, the BOT Model period in Turkey began.

The spread of privatization has brought major changes to the financing of airport operations and in particular, the revenue from passengers and non-aviation services has significantly increased.

Many studies have been conducted and many articles published related to the airport ownership and management Current approaches can be summarized as follows:

Public ownership and management; in most of the countries, the building, development and management of airports is currently carried by public institutions. Ministry of Transport/Civil Aviation Authority's ownership and control of management is common.

Public-private partnership; this application is widespread in the developed and developing countries. BOT Model tenders with limited durations are common. In practice, the ownership remains in the public sector, at the end of the private operation period, all of the buildings and equipment transferred to public. However, in some countries, after the BOT period, with new rental contracts (mostly bidding), private companies are authorized to continue to manage the operations.

Full private management; few countries have fully transferred ownership and management of airports to private companies completely.

\section{Reasons for Privatization, Problems Encountered}

"Public-private partnerships play an important role in bringing private sector competition to public monopolies and in merging the resources of both public and private sectors to better serve the needs of the public that otherwise would not be met" [7]. The reasons for the transfer of airport privatization and ownership from public to private sector can be summarized as follows [5]:

Resource creation (easy access to investment funds),

Moving away from political factors that cause delays (rapid investment),

Greater efficiency in commercial operations, increase in non-aviation activities/revenues,

Transition to profitable and tax-paying business (financial responsibility).

Resource creation and moving away from political factors that cause delays in investments are the most common reasons for privatization. Especially in developing countries, it is the only solution to provide a rapid investment. It is possible to say that, the privatization of terminal services in Turkey has started for this reason. Consequent to the solution, the construction time of terminals decreased to 23 years which was 10-15 years before.

Furthermore, it is known that, private companies more easily and quickly adapt themselves to the developing technologies and modern management approaches than the public sector. Before the privatization of airport operations, 
the logic for the public authorities was; to operate in accordance to the aviation regulations, without any commercial concerns but after the privatizations, this logic has fully altered and airports have became the center of commercial activities and this especially increased the non-aviation revenues. Airports, with many kinds of food and beverage shops and stores increased both in quality and in number and become attractive to not only to passengers but also to accompanying persons and/or visitors. In addition to these, development of other services in airports or in the vicinity areas, such as airport hotels, business centers, conference facilities, art centers, exhibitions, and car parkings can also be mentioned.

In 2005, within the study of 160 airports in total (25 European), it is stated that "the private airport operations are more profitable than the public ones and difference is the output diversification of the non-aviation activities [6]".

However, airport service commercialization comes with many negative effects, such as; the need to avoid extensive investment by private companies, cutbacks on maintenance and repair facilities, reducing necessary spaces for aviation activities to increase commercial areas, higher prices for services, risk of bankruptcy, etc. Therefore, conditions of privatization should be organized very carefully within the contracts. For example, the transfer of the ownership of the London Heathrow Airport to a private company is still under intense critics and every hitch or problem in aviation activities is reflected in the newspapers afterwards (In December 2010, The Guardian [8] and The Telegram [9] reported that the reason of the heavy delays caused by the snowfall for 3-4 days is the privatization itself; it is the result of deficiencies resulting from the privatization. They refer the other countries, which did not transfer ownership to private companies). On the other hand, routing the aviation related activities to the second plan and having large numbers of commercial spaces in the airport terminals are also vastly criticized.

\section{Applications in European Union Countries}

Thoroughly conducted research of the capital airports of 27 European Union countries ${ }^{1}$, public ownership is still in process in 24 of them. In 13 airports public institutions, in 11 public institutions and private companies and in only 3 private companies are realizing the airport operations (Figure 1). In other words, the public ownership has been protected but in the majority of the airports private management have become the more preferred application (\%52).

\footnotetext{
${ }^{1}$ Information regarding the airports has been gathered from the annual reports obtained from official websites (web addresses of these 27 reports are not stated in the resources). In Germany, Frankfurt Airport is chosen, where it has much more air traffic and passenger movements in total than Berlin Airport.
}

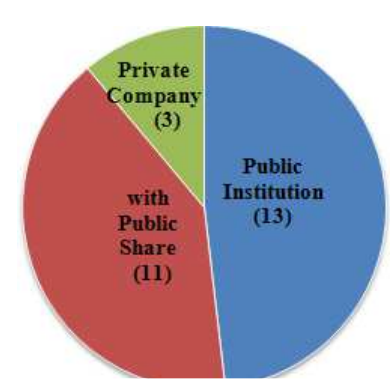

Figure 1. Airport Ownership and Management in European Union Countries.

Ownership and management status of the airports according to the countries are shown in Table 1. As a summary;

Table 1. Airport Ownership and Management in European Union Capital Airports.

\begin{tabular}{|c|c|c|}
\hline $\begin{array}{l}\text { Ownership/Management } \\
\text { Status }\end{array}$ & $\begin{array}{l}\text { Numb } \\
\text { er }\end{array}$ & Country \\
\hline Public (100\%) & 13 & $\begin{array}{l}\text { Bulgaria, Finland, Czech } \\
\text { Republic, Estonia, } \\
\text { Sweden, Spain, Letonia, Lithuania, } \\
\text { Poland, Lüxembourg, } \\
\text { Portugal, Romania, Slovakia. }\end{array}$ \\
\hline $\begin{array}{l}\text { Public } \\
\text { Share }(>50 \%)\end{array}$ & 4 & $\begin{array}{l}\text { France, }(52 \%) \text {, Netherlands }(69,77 \%) \text {, } \\
\text { Slovenia }(50,67 \%) \text {, Greece }(55 \%) \text {. }\end{array}$ \\
\hline $\begin{array}{l}\text { Public } \\
\text { Share }(<50 \%)\end{array}$ & 7 & $\begin{array}{l}\text { Germany }(31,52 \%) \text {, Austria }(40 \%) \text {, } \\
\text { Begium }(25 \%) \text {, Denmark }(40 \%) \text {, Italy } \\
(3,01 \%) \text {, } \\
\text { Hungary }(25 \%) \text {, Malta }(20 \%) \text {. }\end{array}$ \\
\hline Pirvate Company & 3 & $\begin{array}{l}\text { United Kingdom, Ireland, N. Cyprus } \\
\text { (BOT). }\end{array}$ \\
\hline
\end{tabular}

In Germany, Austria, and Italy, regional and local administrations and in Netherlands local municipalities have shares.

Paris Charles de Gaulle and Amsterdam Schiphol Airports have shares $(8 \%)$ respectively.

Fraport AG operates four airports in different countries, including Antalya Airport in Turkey.

Spanish Ferrovial Group owns and operates London Heathrow, Stansted, Glasgow, Aberdeen and Southampton Airports.

Germany based Hotchief Company operates Athens, Budapest, Dusseldorf, Hamburg and Tirana Airports.

Australian based Macquarie Airports Group operates Birmingham, Bristol, Brussels, and Copenhagen Airports.

Larnaca Airport is operated according to BOT Model.

TAV Airports Company, which is the well-known BOT Model airport operator in Turkey, transferred $38 \%$ of her shares to French Aeroport de Paris Group in 2012. TAV operates Adnan Menderes, Atatürk, and Esenboğa Airports terminals and Antalya Gazipaşa Airport (full operation) in Turkey, Tbilisi and Batumi Airports in Georgia (respective share; 76\%), Monastir and Enfidha-Hammamet Airports in Tunisia (67\%), Skopje and Ohrid Airports in Macedonia 
(100\%) and Medina Airport in Saudi Arabia (33\%) [10].

In Estonia Tallinn Airport Ltd, in Finland Finavia, in Spain AENA Group, in Sweden Sweavia and in Poland Polish Airports are operating all of the countries airports as in Turkey (DHMI).

Another significant factor in transition from public to private sector is the high amount of passenger traffic. The 2012 passenger traffic statistics are shown in Figure 2. It is seen that among the eight airports with more than 20 million passengers/year (Amsterdam- Schiphol, Frankfurt, Copenhagen, London Heathrow, Madrid, Paris Charles de Gaulle, Rome and Vienna), 7 of them are under the private sector ownership and/or management. The only exception is the Madrid Airport, which is operated by AENA Group, in Spain. At airports with passenger traffic less than 20 million/year public ownership and/or management is continued. In other words, for airports with high passenger revenues private sectors ownership or management is more appealing.

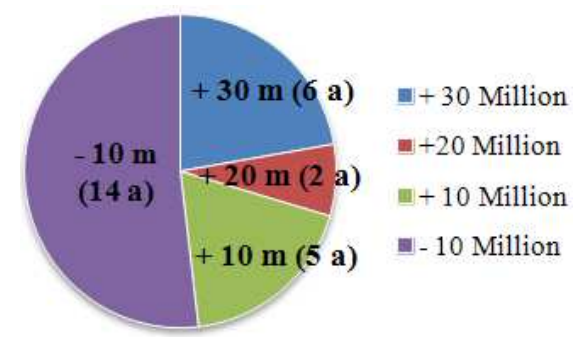

Figure 2. Distribution of European Capital Airports According to Passenger Traffic Movements ( $m$; million a; airports).

\section{Applications in Turkey}

44 of 49 airports, which have regular flights, are operated by DHMI in Turkey. Zonguldak Çaycuma Airport (Zonguldak Private Civil Aviation Industry and Trade Inc.), Antalya Gazipaşa Airport (TAV Gazipaşa Investment, Construction and Management Inc.) and Zafer Airport (IC Içtaş Zafer International Airport Inc.) are operated by private companies under the control and surveillance of the General Directorate of State Airports Authority (DHMI); İstanbul Sabiha Gökçen Airport, which is owned by Undersecretary of Defense operated by public shared institution (HEAŞ; Airports Management and Aviation Industries Inc.), Eskişehir Anatolian University Airport owned and operated by the University (Faculty of Aerospace Sciences) [11].

Privatization of airport terminal operations was initiated by DHMI in 1996 with the BOT Model and today has widespread to all international airports with scheduled services in Turkey. The private sector management is continued by re-lease tenders at the end of first operating periods, which is open to all other private companies. The airport terminals operated by private companies under the BOT model or re-leasing are given below [11];

Antalya Airport international terminal buildings I and II, domestic terminal and CIP (Fraport AG and IC İçtaş Antalya Airport Terminal Investment and Management Inc.),
Atatürk Airport domestic and international terminal buildings and general aviation terminal (TAV İstanbul Terminal Management Inc.),

Ankara, Esenboğa Airport domestic and international terminal building (TAV Esenboğa Investment, Construction and Management Inc.),

İzmir, Adnan Menderes Airport domestic (under construction) and international terminal buildings and CIP (TAV EGE Terminal Investment Construction and Management Inc.),

Muğla, Dalaman Airport international terminal building (ATM Airport Construction and Management Inc.),

Muğla, Milas-Bodrum Airport international terminal building (Mondial Milas-Bodrum Airport International Terminal Management and Investment Inc.),

İstanbul Sabiha Gökçen Airport domestic and international terminal building (İstanbul Sabiha Gökçen Airport Construction Investment and Management Inc.).

During the BOT Model privatization of airport terminals, the passenger warranty is given to the private operators, but in the re-leasing periods, no warranty issued. İstanbul's new airport and Çukurova (Adana-Mersin) Airport, tendered according to the BOT Model by DHMI for full airport building and operations, will be in operation in 2014 and 2017 respectively. These applications do not transfer any ownership rights.

The analysis of yearly passenger traffics of airports operated by private companies shows that only two airports (Atatürk 45,1 million and Antalya 25,1 million) have more than 20 million passengers, and only one airport (İstanbul Sabiha Gökçen 14,7 million) has more than 10 million yearly passenger movements [12]. Other airports have less passenger movements. In Turkey, private companies are also operating the airports with less passenger traffic movements, which is contrary to European countries.

\section{Evaluation of Turkey's Approach}

In last 20 years, the total passenger traffic has increased $4 \%-4,5 \%$ yearly in the World. Turkey has experienced more than $20 \%$ increasement starting from 2003. Today, passenger movements continue to increase at $10 \%$ levels (Figure 3). In 2012, 130,4 million passenger movements was achieved [12], and it is expected to have 350 million movements in 2023[13]. Commercial aircraft traffic increased by $\% 6,1$ compared to the previous year, reached to 946.897 aircraft (Figure 4).

Airport and terminal operations in Turkey, in terms of private sector participation is far more robust than in many European Union countries. The private sector management and operations started with terminal buildings in 1996, with the high increase of passenger traffic movements it is widely accepted as a natural consequence, and BOT Model applications have become a common practice for all international airports. In recent years, this practice is more widened with covering all airport construction and operations. Today, terminal buildings in seven airports and all facilities 
in two airports (Antalya/Gazipaşa and Zafer) are managed and operated by private sector; and two more airports are under construction.

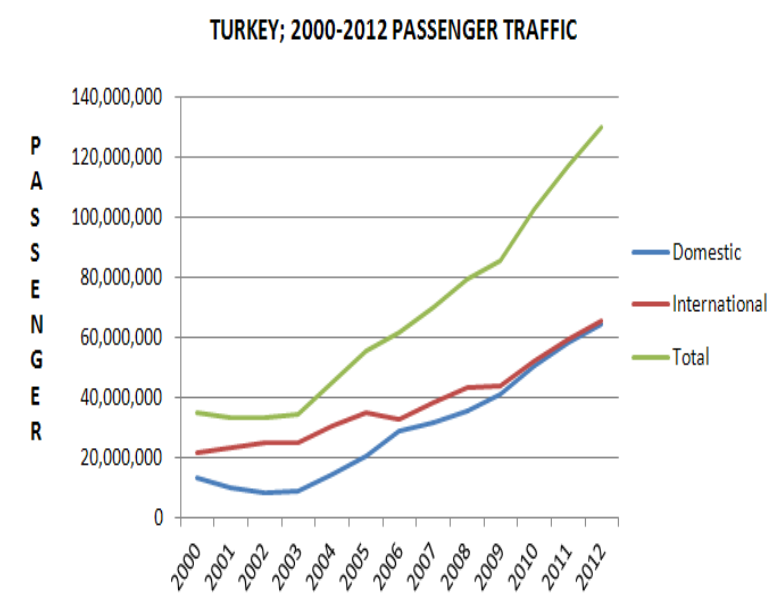

Figure 3. Turkey, 2000-2012 Domestic-International-Total Passenger Traffic, (Data source; DHMI Annual Statistics Reports [12]).

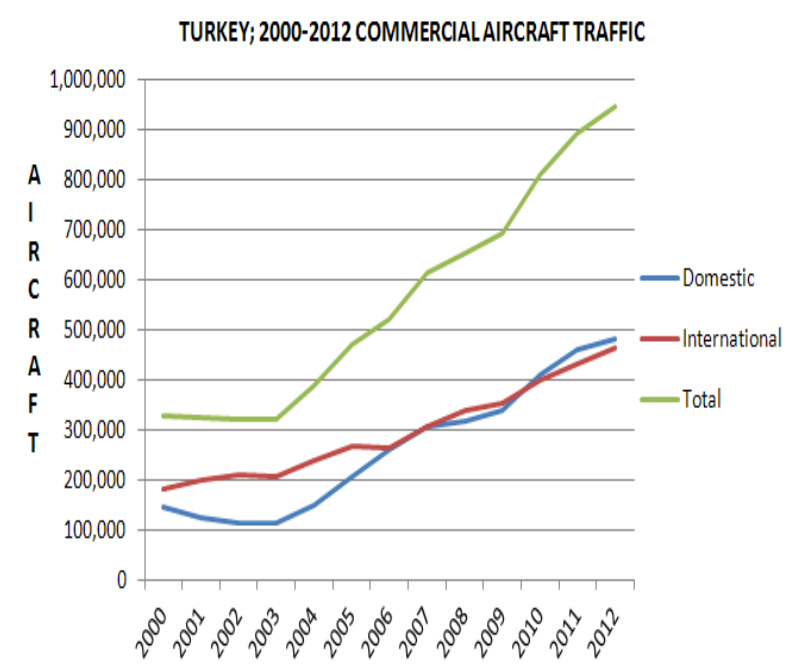

Figure 4. Turkey, 2000-2012 Domestic-International-Total Commercial Aircraft Traffic, (Data source; DHMI Annual Statistics Reports [12]).

In Turkey, BOT Model is defined as "a special funding model for high-technology or high financial resource required projects, to be realized by the capital (foreign) company, where the payment of investment amount (including revenue) is rewarded by the sell of goods or services during a specified period of operation time from these investment" by the article 3 of the Law numbered 3996 in 1994. In this context, the ownership of airports is not transferred to private sector (concession contracts up to 49 years). "Concession period is the span of time granted by the government to the private sector within which the private sector is responsible for the financing, construction and operation of a BOT project" [14]. The most criticized issue of the BOT projects is the concession periods, where the winner of the bidding is determined by the given operation time and it is always the possibility to come out with very short times (such as three, four years) which are not enough for profitable operations [15].

BOT is considered as a "win-win" situation for all parties concerned [16]. However, "Is the BOT Model for airports as a stand-alone application correct and sufficient application for privatization?" The model extremely shortens the construction period, which use to last several years earlier, provides the possibility of more modern and profitable business approaches, it has significant contribution to the increase of the number of passengers and the nonaviation activities and revenues are widening. However, because of short operation durations, the users and organizations intensively criticize the high level of service charges introduced to both the airlines and passengers. Establishing an appropriate concession period is a vital subject.

On the other hand, after the successful practices, some of the Turkish operating companies began new businesses in the foreign countries. This model of transferring management of operations to the private sector without ownership is expected to expand further around the world not only for airports or for terminals in aviation, also in many other sectors such as road, bridge, and harbor projects.

The analysis shows that, except in the United Kingdom and Ireland, European Union countries are also not in favor of transferring the ownership of airports. The debates in UK related to $100 \%$ ownership transfer to foreign company are still going on with intensive critics. It seems more appropriate that the ownership of the airports stay in the public, both from the political point of view and the significant importance on the social and commercial development. USA and Canada continues in this manner as well. Public ownership of airports is not an obstacle for the contribution of private management and operations. On the contrary, controlled (subject to contract) operations could be seen as a more appropriate practice for balancing aviation and nonaviation activities.

Success in the airport management and operations by private sector during past 15 years of practice has approved itself. In this context, to continue BOT Model for Turkish airports seems to be most appropriate approach for the involment of private sector in airport management and operations. However, short duration of operation periods need to be prevented to overcome excessive commercialization and high service charges. This may be avoided easily by the tender mechanism by including clarified specifications.

On the other hand, the examination of the pre-tax earnings of the Turkish airports indicates that only five airports operated by DHMI are making profit [17]. İstanbul Atatürk and Antalya Airports are by themselves compensating the loss of all the other airports (Sabiha Gökçen Airport is also profitable; the amount shown in the Table 2, does not include the earnings of the private operating companies). 
Table 2. Turkish Airports 2011/2012 Passenger Movements and Pre-tax Earnings, (Source; DHMI Annual Report [17]).

\begin{tabular}{|c|c|c|c|}
\hline \multirow{2}{*}{ Airports } & \multirow{2}{*}{$\begin{array}{l}2011 \\
\text { Passenger }\end{array}$} & \multirow{2}{*}{$\begin{array}{l}2012 \\
\text { Passenger }\end{array}$} & \multirow{2}{*}{$\frac{2011 \text { Pre-tax }}{\text { Earnings } 000 \text { TL }}$} \\
\hline & & & \\
\hline İstanbul Atatürk & 37.394 .694 & 45.091 .962 & 797.104 \\
\hline Ankara Esenboğa & 8.485 .467 & 9.273 .108 & -27.080 \\
\hline İzmir Adnan Menderes & 8.523 .533 & 9.355 .902 & 33.062 \\
\hline Antalya & 25.027 .657 & 25.096 .144 & 529.335 \\
\hline Muğla Dalaman & 3.732 .374 & 3.811 .958 & 25.069 \\
\hline Milas Bodrum & 3.388 .335 & 3.530 .460 & 55.411 \\
\hline $\begin{array}{l}\text { İstanbul, } \\
\text { Gökçen }\end{array}$ & $\mathrm{a}_{13.124 .670}$ & 14.686 .052 & 20.363 \\
\hline Zonguldak, Çaycuma & 20.462 & 27.711 & -336 \\
\hline Antalya, Gazipaşa & 14.130 & 75.886 & -2.182 \\
\hline Total & 99.711 .322 & 110.949 .183 & 1.430 .746 \\
\hline Other Airports & 17909147 & 19402437 & -601.827 \\
\hline General Total & 117.620 .469 & 130.351 .620 & 828.919 \\
\hline
\end{tabular}

This brings the case that, at what extend the public gains has to be shared with the private companies.

\section{Conclusion and Suggestions for Tur- key}

In most of the European Union countries and Turkey, the ownership of airports and terminals are not transferred to the public. On the other hand, private management has become the more preferred application.

Turkey is a successful example to the world with the BOT projects and it is indisputable fact that they provided significant contributions to the development of the Turkish civil aviation. BOT model seems to be the correct approach for the future airport and terminal investments. However, an automated process for re-leasing should not to be considered as the only alternative for continuing operations. Detailed and transparent analyses should be performed related to public benefits, and the opportunity to create public-private sector partnerships, on more realistic winwin scenarios should be considered.

For the partnership structure, as well as the private companies, the participation of municipalities and chambers of commerce's need to be studied in accordance with all the advantages and disadvantages related to their impact on management issues.

In these studies, France (ADP; Aeroport de Paris [18]), Germany (Fraport [19]) and Netherlands (Schiphol [20]) airports organizational structures and management practices can be modeled.

\section{Note}

The short version of this paper was submitted to the " 1 st International Aviation Management Conference held on December 7, 2012 (intavic.thk.edu.tr/). The proceeding of the Conference is not available on the web and, can be obtained only from the University of Turkish Association Aeronautics and Astronautics.

\section{References}

[1] Doganis Rigas."The Airport Business", Routledge, London, p. 1-5, 1992.

[2] ICAO Doc 9082-ICAO's Policies on Charges for Airports and Air Navigation Services, 8th Edition, ICAO publication, Montreal, p. 4-15, 2009.

[3] ICAO Annex 14; Aerodromes Design and Operations, Volume 1, 4th Edition, ICAO publication, Montreal, 2004.

[4] Kazda Antonin and Caves Robert E. "Airport Design and Operation”, 2nd Edition, Elsevier Ltd., UK, p. 5-6, 2007.

[5] Vasigh Bijan, Fleming Ken and Tacker Thomas, "Introduction to Air Transport Economics - From Theory to Application”, Ashgate, Burlington, p. 115-121, 2008.

[6] Ouma Tae.H., Adlerb Nicole and Yua Chiunyan "Privatization, corporatization, ownership forms and their effects on the performance of the world's major airports", Journal of Air Transport Management, 12, p. 109-121, 2006.

[7] Zhang Xueqing, Chen Shu, "A systematic framework for infrastructure development through public private partnerships”, Elsevier, IATSS Research, SciVerse ScienceDirect, 2012.

[8] Clark Neil (2010), "Why we should nationalize our airports", The Guardian, Available http://www.guardian.co.uk/commentisfree/2010/dec/21/nati onalise-airports-baa?INTCMP=ILCNETTXT3487, 2010.

[9] Milward David, "Was the privatization of our major airports a mistake, The Telegraph, December 20, 2010". Available http://www.telegraph.co.uk/news/uknews/road-and-railtransport/8214827/Was-the-privatisation-of-our-majorairports-a-mistake.html, 2010.

[10] TAV Airports, “Annual Report, 2011”, İstanbul, p. 32-61, 2012, Available; http://www.tavhavalimanlari.com.tr/enEN/Documents/FaaliyetRaporuTR.pdf.

[11] Turkish Civil Aviation Council, 2011 Sectorial Report, [The Union of Chambers and Commodity Exchanges of Turkey (TOBB)], Ankara, p. 1-5, 2011, Available; http://www.tobb.org.tr/Documents/yayinlar/TOBB_havacili k_meclis_sektor_2012.pdf.

[12] Turkey, "DHMI 2012 Statistics", Available; http://www.dhmi.gov.tr/istatistik.aspx.

[13] 10th Transport Council (Target 2023)", Consolidated Report, the Ministry of Transport, Maritime Affairs and Communications (27 September-1 October 2009), İstanbul, pp. 552, 2009 , http://www.ulastirmasurasi.org/tr/sura_raporlari.html.

[14] Hanaoka Shinya, Palapus Hazel Perez, "Reasonable concession period for build-operate-transfer road projects in the Philippines", Elseveir, International Journal of Project Management-SciVerse ScienceDirect, 30, p. 938-949, 2012.

[15] Kaya Ergun, Gerede Ender, Başar Mehmet, Kuyucak Ferhan 
and Sürmeli Arda, "BOT Model in Airports", Journal of Public Administration, Vol. 40, Issue 2, p. 21, 2007.

[16] Walker C., Smith A.J., "Privatized Infrastructure-The BOT Approach", Thomas Telfrod Publications, London, p. 10, 1999.

[17] Turkey, "DHMI Annual Report - Statistics (2011"), DHMI Publication, Ankara, Turkey, p. 212, 2012.

[18] “Aeroport de Paris, Registration Document” (2011), Available; compa-
ny.com/Labrador/EN/ADP/2011RegistrationDocument/.

[19] “Corporate Governance Code of Fraport" (2012), Available; http://www.fraport.com/content/fraport/en/misc/binaer/thefraport-group/corporate-governance-

code/jcr:content.file/corporategovernancecode-stand-14-122012-final.pdf.

[20] “Corporate Governance of Schiphol Group (2013), Available;

http://www.schiphol.nl/SchipholGroup/InvestorRelations/C orporateGovernance/CorporateGovernance.htm. 